\title{
PROPAGATION OF A FLOODWAVE IN KARST DURING ARTIFICIALLY GENERATED RECESSION - CASE STUDY OF BANJICA SPRING (BELA PALANKA, EASTERN SERBIA)
}

POPLAVNI VAL NA KRASU OB UMETNO POVZROČENI RECESIJI - PRIMER IZVIRA BANJICE (BELA PALANKA, VZHODNA SRBIJA)

MILENA ZLOKOLICA-MANDIĆ1,3 \& JELENA ĆALIĆ-LJUBOJEVIĆC ${ }^{2,3}$

${ }^{1}$ Geozavod HIG, Karadjordjeva 48, 11000 Beograd, Serbia and Montenegro; e-mail: zis@beotel.yu

${ }^{2}$ Geographic Institute "Jovan Cvijić”, Serbian Academy of Sciences and Arts, Djure Jakšića 9, 11000 Beograd, Serbia and Montenegro; e-mail: jcal@sezampro.yu

${ }^{3}$ Student Speleologic and Alpinistic Club (ASAK), Studentski trg 16, 11000 Beograd, Serbia and Montenegro 
Milena Zlokolica-Mandić \& Jelena Ćalić-Ljubojević: Propagation of a floodwave in karst during artificially generated recession - case study of Banjica spring (Bela Palanka, Eastern Serbia)

During hydrogeological research in the area of the north-eastern foothills of Mt. Suva Planina in Eastern Serbia, a borehole of $100 \mathrm{~m}$ of depth was drilled in the vicinity of a lukewarm spring, Banjica. The borehole had an artesian discharge, which caused artificially generated recession in the adjoining spring Banjica. During this hydrodynamical test, great quantities of precipitation occured in the hinterland of the spring, having the effect of a floodwave. The presence of two types of karst is obvious in the field - confined karst and covered karst. The hydrogeological response to the floodwave during artificially generated recession proved the presence of deep-seated karst also. This can be detected by comparative analysis of the hydrograph of the Banjica spring and the graph of pressures in the borehole. In this way, not only the presence, but also the characteristics of the karst can be proved (e.g. dimensions and types of karst conduits, relative age of karst, size and extension of the aquifer, etc.).

Key words: karst hydrogeology, hydrodynamical test, floodwave, artificial recession, types of karst, Eastern Serbia.

MilenaZlokolica-Mandić \& Jelena Ćalić-Ljubojević Poplavni val na krasu ob umetno povzročeni recesiji - primer izvira Banjice (Bela Palanka, Vzhodna Srbija)

V sklopu hidrogeoloških raziskav severovzhodnega vzno•ja Suve planine v Vzhodni Srbiji, je bila v bli•ini toplega izvira napravljena $100 \mathrm{~m}$ globoka vrtina. Dotok v vrtino je bil arteški, kar je povzročilo umetno recesijo v izviru Banjici. Tekom tega hidrodinamičnega poizkusa je bilo v zaledju izvira veliko padavin, ki so povzročile poplavni val. Na terenu je mogoče jasno razločiti dva tipa krasa: ujeti in pokriti kras. Hidrogeološka reakcija na omenjeni poplavni val med umetno povzročeno recesijo dokazuje tudi obstoj globokega krasa. To je bilo mogoče odkriti s pomočjo primerjave hidrograma Banjice in krivulje pritiska $\mathrm{v}$ vrtini. Na ta način ni potrjen le obstoj krasa, ampak tudi njegove značilnosti (npr. velikost in tipi kraških prevodnikov, relativna starost, velikost in obseg vodonosnika, itd.).

Ključne besede: hidrogeologija krasa, hidrodinamični preizkus, poplavni val, umetna recesija, tipi krasa, Vzhodna Srbija. 


\section{LOCATION AND GENERAL CHARACTERISTICS OF THE RESEARCH} AREA

The research area is situated in the south-western part of the Carpatho-Balkanides in Eastern Serbia. Relief and hydrogeological characteristics of the area result entirely from the geological composition and tectonic pattern.

The most conspicuous element of the relief is Mt. Suva Planina (with the highest peak Trem, $1810 \mathrm{~m}$ a.s.1.), the central part of which is a karstified levelled surface at an average elevation of 1300-1500 m. That is a gentle anticline, with the core composed of clastic sediments of Devonian, Carboniferous and Permian (D, C, P). The next in that sequence are Mesozoic carbonates, with a small presence of clastites at the beginning of transgression. Dominant carbonates are thick- to thin-bedded limestones, which were continually deposited from Malmian to Aptian $\left(\mathrm{J}_{3}{ }^{3}-\mathrm{K}_{1}{ }^{4}\right)$. Presence of dolomites and marls is minimal. On the eastern rim of the anticline, there is the Koritnica basin, with clastic sediments of the Oligocene, and Cretaceous limestones in the base. The thickness of Oligocene sediments is directly dependent on the amount of tectonic movements along diagonal faults, and on erosion, but does not exceed $300 \mathrm{~m}$. The eastern rim of this structural unit is a regional dislocation, which extends to the north across the Danube River to Romania, while to the south it extends to Bulgaria. To the east from the dislocation, there is a geostructural unit called Šljivovićki Vrh, in which Barremian-Aptian $\left(\mathrm{K}_{1}^{3-4}\right)$ thick- to thin-bedded limestones were deposited over Palaeozoic and Mesozoic clastites. According to the previous notions, the Banjica spring was attributed to this unit. At the northern contact, there are Miocene and Pliocene $(\mathrm{M}, \mathrm{Pl})$ marls, clays and sands (Fig.1).

\section{HYDROGEOLOGICAL MODEL OF THE AREA}

A clearly outlined hydrogeological function of base, lateral and covering aquicludes, as well as the situation of the collector of groundwater, direct the formation of a wide front of underground accumulation along the Oligocene sediments, with the function of covering aquiclude (confining formation; Fig.1). The groundwater accumulation formed in that way discharges through overflow karst springs Mokra and Divljana. Discharges of karst springs $\left(0,1>\mathrm{Q}<1 \mathrm{~m}^{3} / \mathrm{s}\right)$ are directly dependent on elevations of contact. The collector function of limestones (below the Oligocene sediments as a covering aquiclude) was unknown up to now and was proven during the research and interpretation of data for the spring Banjica. This reveals the possibility of taking additional quantities of groundwater - instead of former 5-7 1/s, quantities could increase up to $25 \mathrm{l} / \mathrm{s}$.

\section{OUTFLOW FROM THE DRAINAGE AREA}

The only surface stream of this area is the Koritnica River, formed by the Koritnica spring. Along its flow towards the Nišava River, the Koritnica receives tributary waters of the karst springs Divljana and Mokra (Mt. Suva Planina), while in the town Bela Palanka, it receives water of the karst spring Vrelo (area of Šljivovićki Vrh). It was proven by hydrogeological measurements that there is no diffuse emergence or sinking of waters in the river bed. Discharge measurements on the karst springs (Koritnica, Divljana, Mokra and Vrelo) showed the relation Qmin:Qmax 1:10, in extreme 1:30 during one hydrological cycle, while for the spring Banjica, this relation does not exceed 1:1,5. The discharge curves of the karst springs show relatively fast propagation 

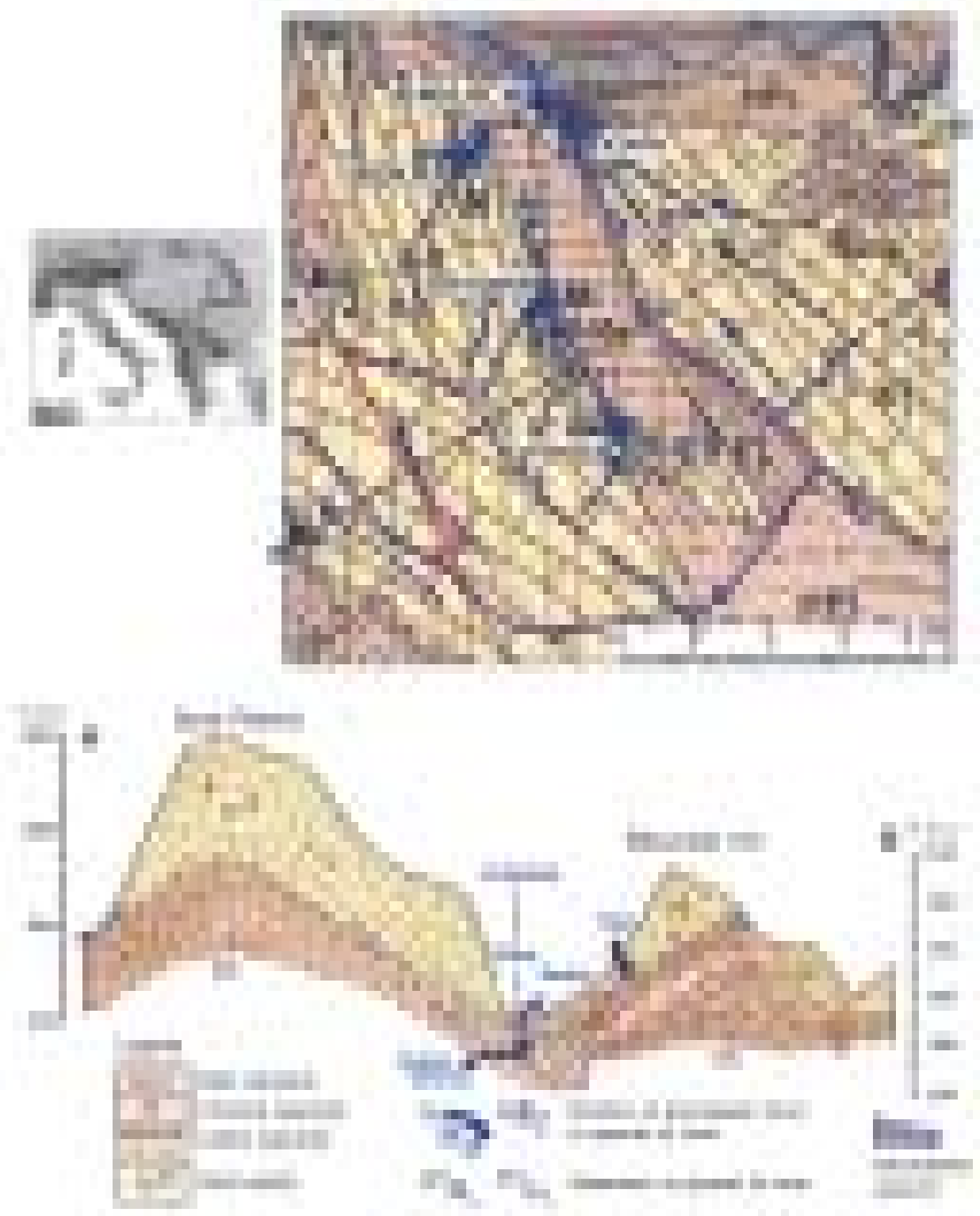

Fig.1: Basin of Bela Palanka, with the surrounding terrain - schematic hydrogeological map and hydrogeological profile (according to Čubrilović 1969, 1992; modifications by Zlokolica-Mandić 2001). 

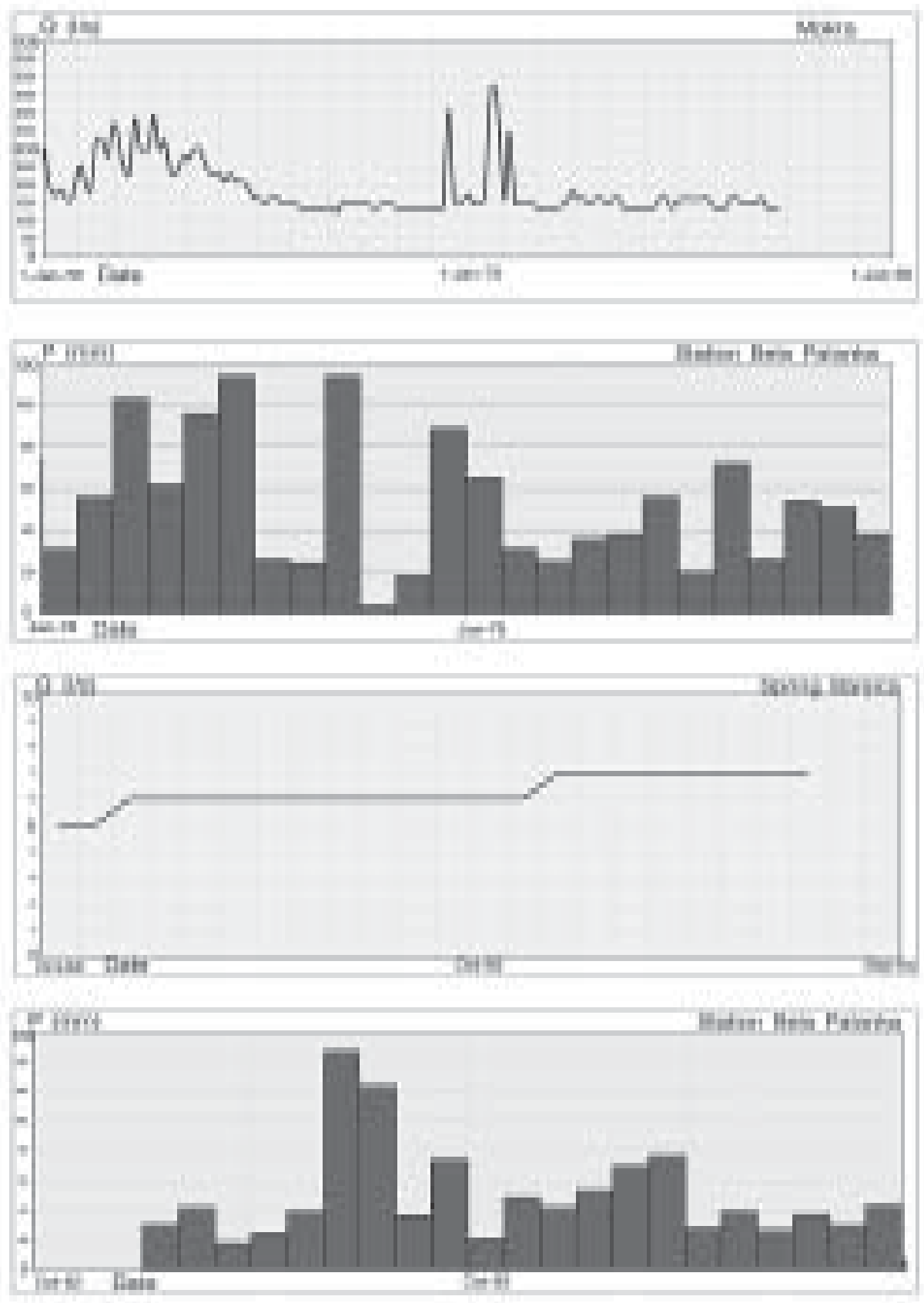

Fig.2: Hydrograms of karst spring Mokra, and the Banjica spring . 

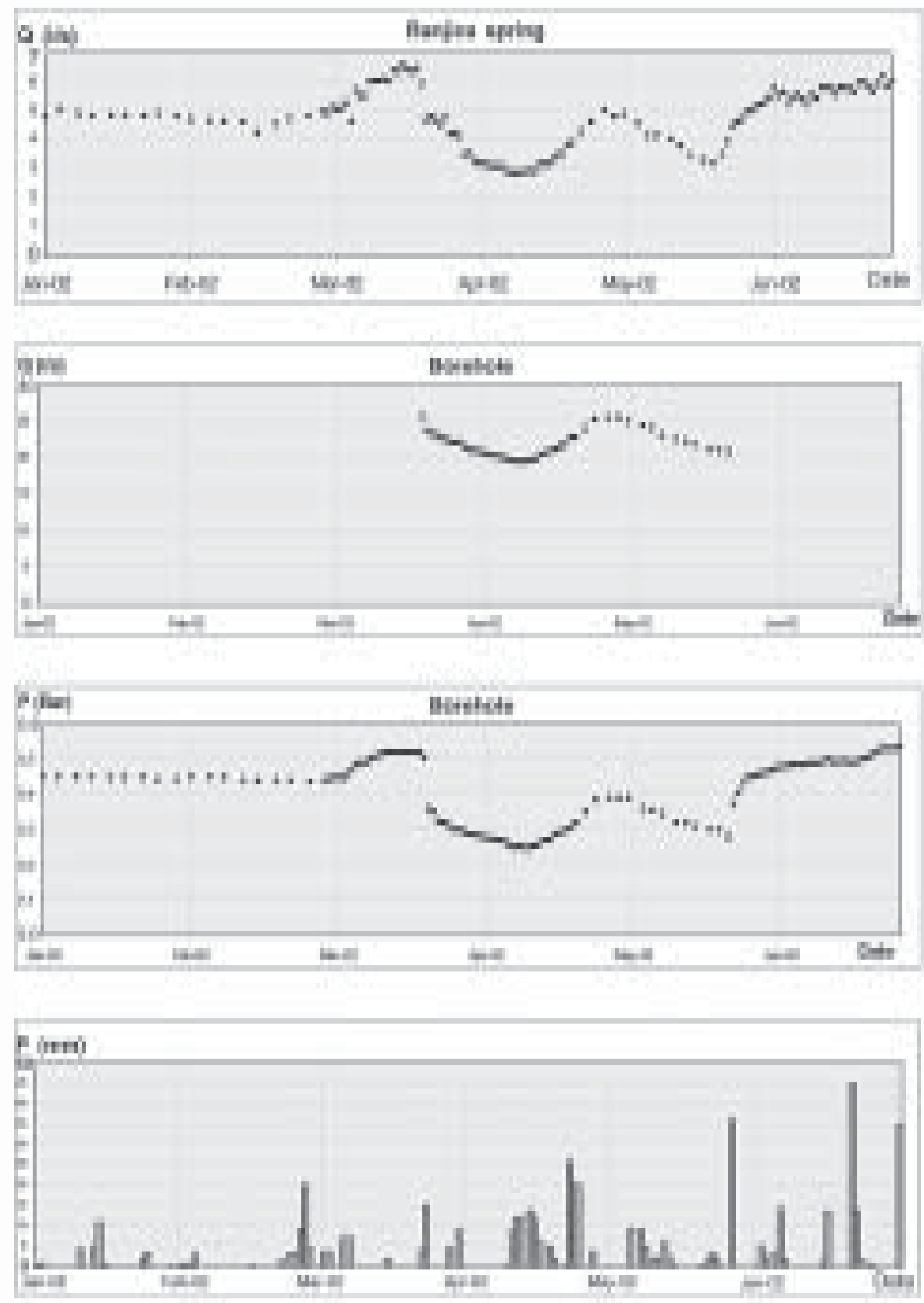

Fig.3: Relations between spring and borehole discharges, pressure in the borehole, and precipitation, during the hydrodynamical test. 
of precipitation waters (up to 15 days) and insignificant impact of precipitation on discharges in the vegetation period of a year, so that maximum $30 \%$ of precipitation drains through the karst springs (Fig.2). As opposed to the karst springs, the spring Banjica, in the natural outflow regime, minimal and maximal discharges were not recorded, but only a gradual increase or decrease of discharge, with minimal oscillations during the year. Fig.2 shows typical hydrograms of the karst spring Mokra and of the spring Banjica.

\section{COURSE AND RESULTS OF RESEARCH}

On the locality of Banjica spring, at the distance of about $20 \mathrm{~m}$ from the natural spring, a 100 $\mathrm{m}$ deep borehole was made, which showed the presence of limestones starting from 23rd meter and further down. Three intervals of significant water input were registered in the limestone sequence, so the borehole gave in total $60 \mathrm{l} / \mathrm{s}$ of water, with artesian discharge, followed by the decline of capacity of the spring. After the borehole was closed, the pressure of about 0.5 bar was registered, as well as the initial capacity of the spring (about $5 \mathrm{l} / \mathrm{s}$ ). During the hydrodynamical test, with the borehole capacity of $25 \mathrm{l} / \mathrm{s}$ (limited by a top valve), changes of spring discharge were registered, in accordance with the changes of pressure in the borehole (Fig. 3). The borehole was opened for 65 days, which caused the effect of recession at the spring. In the same period, on both the borehole and the spring, propagation of precipitation was registered (with the characteristics of a 'floodwave'), and lasted 44 days, which is not a characteristic of this spring in natural conditions of outflow (Fig. 2).

Synchronic reactions of the spring and the borehole undoubtedly prove that their waters originate from the same aquifer. Opening of the borehole led to lowering of the groundwater level, which enabled an additional feeding of the aquifer by precipitation waters. It was not possible to recognize this phenomena on the spring hydrogram in natural conditions. Factors which influence the duration

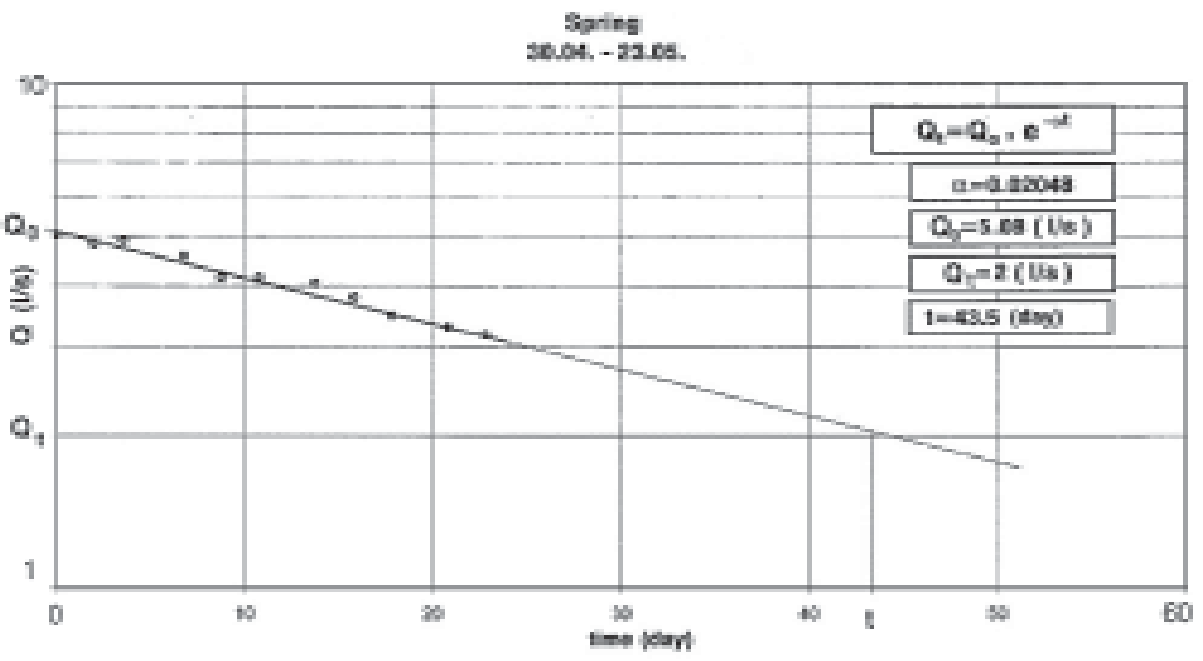

Fig.4: Calculation of hydrogeological parameters for the Banjica spring. 
of propagation of a floodwave are, besides the dimensions of the conduits (maximization) and their mutual connections, also the shape, size and distance of the drainage area, as well as the inclination of the impermeable basis, i.e. hydraulic gradient. The shapes of spring and borehole hydrograms (during the outflow) point to the aquifer of relatively homogeneous characteristics, and to smooth feeding. Discharge of the borehole point to the aquifer of much greater dimensions than it was previously thought. The hydrogram excludes the possibility that the drainage area belongs to the zone of Šljivovićki Vrh. On the contrary, it favours deep siphonal circulation beneath the covering aquiclude of Oligocene sediments.
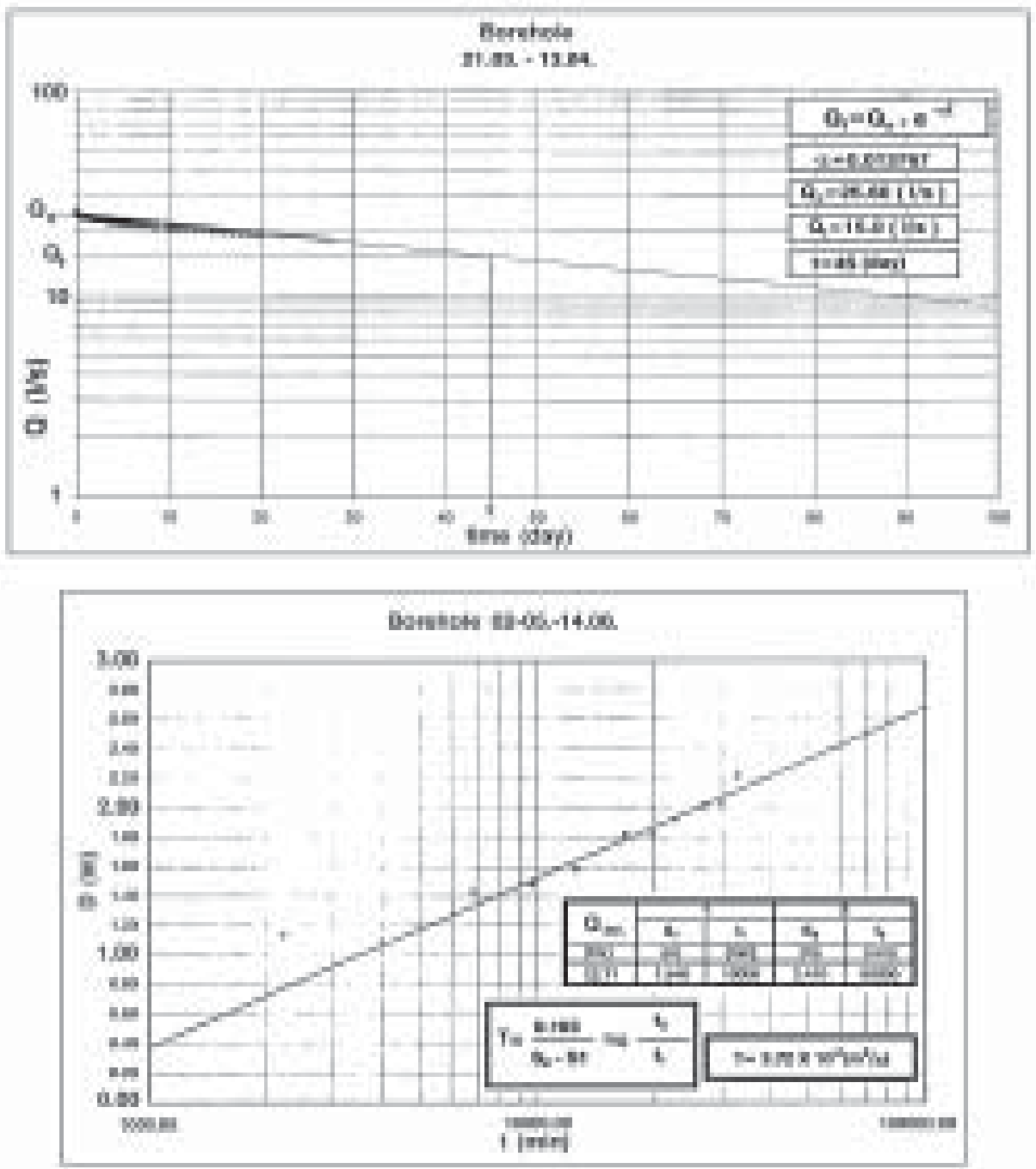

Fig.5: Calculation of hydrogeological parameters for the borehole. 
By graphical/analytical processing of data (Fig. 4, Fig. 5), the parametres of settings were calculated: coefficient of discharge (a) and coefficient of transmissivity (T), which mutually correspond and point to the conduits of $\mathrm{cm}-\mathrm{dm}$ dimensions (Zlokolica 1989). These dimensions of karst conduits were confirmed by the drilling as well.

The slight difference in the obtained values of coefficients of discharge between Banjica spring $\left(a_{\mathrm{s}}=0,020\right)$ and the borehole $\left(\mathrm{a}_{\mathrm{b}}=0,013\right)$, with the great differences of discharges $\left(\mathrm{Q}_{\mathrm{s}}=5 \mathrm{l} / \mathrm{s}\right.$ and $\mathrm{Q}_{\mathrm{b}}=25,6 \mathrm{l} / \mathrm{s}$ ) point to the system of developed and connected conduits of homogeneous, although small dimensions, which host great quantities of groundwater.

\section{CONCLUSIONS}

Due to the specific situation within the hydrogeological structure, as well as to the quantities of waters that flow out through the borehole and the Banjica spring, and to calculated parametres of the setting and duration of the floodwave, it has been undoubtedly proven that:

- the drainage area of the Banjica spring belongs to Mt.Suva Planina, and not to Šljivovićki Vrh;

- there is circulation of groundwater below the covering aquiclude and below the level of local erosional basis (which altogether point to covered and deep-seated karst)

Temperatures of waters are in favour of this - on springs Banjica and Mokra, the water temperature is $16-19^{\circ} \mathrm{C}$, while on the other springs it does not exceed $12^{\circ} \mathrm{C}$. Higher temperature is most probably caused by igneous intrusions which follow the regional dislocation in the Koritnica valley, although their existence was not confirmed in the vicinity of the springs.

Specific hydrogeological settings of the Banjica spring - the existence of three aquicludes (base, lateral and covering) - have hidden its karstic characteristics, and have contributed to its non-karstic regime. However, artificial generation of recession revealed the karst characteristics, thanks to enforced emptying of the karst aquifer through the borehole.

Although these hydrogeological settings are very favourable for horizontal and vertical development of karst, there is still no notion about any cave of traversable size in the whole area, apart from several small pits (not more than $100 \mathrm{~m}$ deep) at the high karst levelled surface on Mt.Suva Planina.

\section{REFERENCES}

Čubrilović, P., 1969: Hidrogeološke odlike sliva Ju•ne Morave.- Fond stručne dokumentacije, Geozavod, Beograd.

Čubrilović, P., 1992: Godišnji izveštaj o hidrogeološkim istra•ivanjima u Beloj Palanci tokom 1991.- Fond stručne dokumentacije, Geozavod, Beograd.

Zlokolica, M., 1989: Proticaji karstnih vrela i dimenzije karstnih kanala - veličine koje se mogu porediti.- Naš kršs, 26/27, 83-88, Sarajevo.

Zlokolica-Mandić, M., 2001: Elaborat o rezervama podzemnih voda Banjice kod Bele Palanke.Fond stručne dokumentacije, Geozavod, Beograd. 